\title{
COMPOUNDING AS THE MOST PRODUCTIVE TYPE OF WORD FORMATION IN ENGLISH FICTION TEXTS (BASED ON THE SERIES OF NOVELS BY GEORGE MARTIN “A GAME OF THRONES”)
}

\author{
O. Shumenko, PhD in Philology, Associate Professor; \\ K. Vasylenko, student \\ Sumy State University, \\ 2, Rymskogo-Korsakova St., Sumy, 40007, Ukraine \\ E-mail:shuma-81@ukr.net, loveinsummertime@gmail.com
}

The article is concerned the study of the peculiarities of the process of word-formation in modern English. New words appear constantly, most of them are formed by word-formation. In those languages where the process of compounding is available, it is a powerful means of replenishing the vocabulary and improving the grammatical structure of the language. Compounding in comparison with derivation is a system more active, mobile and open. Compounding is one of the most productive ways of word formation. Words with this method are formed by the addition of two stems.

Key words: compounding, word formation, compound word, word-formation model, productive type.

DOI: 10.21272/ Ftrk.2018.10(1)-14

Introduction. Compounding is one of the most ancient ways of word formation which has kept productivity at the present stage of development of English language. The existence of language is impossible without continuous development, which leads to the emergence of new words. New words arise when it is necessary to define the new subjects or there is a need for renaming already known objects. New words are formed from already existing elements of the language for existing word-formation models. The vocabulary of English, as well as any other, is in a state of continuous change. One of the regularities of the development of the vocabulary of the language is the addition of new words to it. Replenishment is due to word formation. In this process, the connection between the wordform and the grammar, in particular with the morphology, is manifested. New words are written in accordance with the grammar of English, according to the sample of already existing words in the language and relate to a certain part of the language.

The vocabulary of the language is constantly changing. Among the other sections of the Germanic language, the compounding is marked by a large number of research on the productive processes of the formation of new words, in particular in English. Compounding is a common method of formation of new words in all areas of language. It is most clearly manifested in fiction. A distinctive feature of modern word formation is the widespread distribution of composite formations. A compound word, on the one hand, serves as a way of curtailing free phrases, phraseological unit, or even microtext, and on the other hand, reflects the tendency to combine lexical units integrated not only with syntactic relationships, but also associatively-correlated in the text.

The article rests on recent research in the scientific works of prominent domestic and foreign scientists as H. Marchand, O. Jespersen, N. Chomsky, O. M. Bortnichuk, S. A. Vengerov, Yu. A. Zatsnyi, P. M. Karashchuk, A. O. Kolesova, O. S. Kubryakova, A. D. Meshkov, N. A. Nikolina, V. M. Pitel, M. D. Stepanova, V. P. Tsaryov.

The relevance of the study is determined by the need to study this vocabulary, since the number of new lexical units in this sphere annually increases. At present, the process of word-building pays considerable attention in modern lexicology, because this way of wordformation helps to form new words at a rapid pace.

(C) Shumenko O., Vasylenko K., 2018 
The objective of the article is to study the peculiarities of the formation and functioning of compound words in modern English.

The tasks of this research are: (1) to explore ways to replenish the English vocabulary; (2) to analyze the concept of word formation; (3) to define its main methods in contemporary English; (4) to define the concept of a compound word and productive wordformation models of compound words; (5) to characterize the phenomenon of compounding in modern English; (6) to distinguish the ways and difficulties of translating the compound words of the English language texts based on the material of the series of novels by George Martin "A Game of Thrones".

The object of the study is the compound words of the English language, formed by combining two or more stems and their translation on the material of the cycle of novels by George Martin "A Game of Thrones". The subject of the study is the pragmatic and functional features of such units on the material of the cycle of novels by George Martin "A Game of Thrones".

During the research, the following methods were used: general scientific, descriptive, linguostylistic, continuous sampling method, method of translation analysis.

The results of the research. Enrichment of the vocabulary is one of the processes of adapting the language system to the new conditions of real communication due to changes in the space of the extra-language environment. The ways of replenishing the vocabulary of the English language are conversion, affixation, word formation, abbreviation, generalization, specification, metaphor, degradation, elevation.

Word formation is the section of linguistics, which studies the mechanism of the formation of derivative words. A subject of studying of word formation is consideration of ways of word formation and determination of their productivity, classification of derivative words taking into account their word-formation structure and word-formation value [1]. The research of all word-formation means of language belongs to problems of word formation.

Types of word formation: (1) semantic word formation - the use of existing words in a new meaning: reduplication - the formation of a new word by repeating the stems; (2) syntactic - the formation of compound words; (3) morphological - the creation of words with affixes: the suffix is a derivative element at the end of the word (between the root and the end), which is a productive element of the word-formation, the prefix is a morpheme that stands before the root of the word and modifies its meaning, the infix is an affix that occurs within the framework; (4) telescopy is a phenomenon when a new word arises from the fusion of the full stem of one word with the abbreviated stem of another, or from the fusion of abbreviated stems of two words [2, c. 194].

English word formation is also defined as the model of motivated (secondary) names, that is, word-building models. The leading feature of the word-making model is abstractness. The ability of model to abstract to make it a kind of matrix in which "new" words are printed, and it provides an opportunity to perform a word-formation function [3, c. 125]. Not all methods of word formation are used equally. In order to determine the trend of the formation of new words, it is important to explore each of the methods of word formation.

Compound words, obviously, can be defined as the union of two or more words capable of functioning as a single word, as one unit. Compound words consist of two or more root morphemes. Compound words make up a large layer of everyday vocabulary, since words have totally different meanings. The most common classifications of compound words in English are classifications in parts of the language, that is, those based on the morphological approach. It was found that if each part of the language could be combined with any other, forming compound words, then the English word formation would have at its disposal 196 models [4, c. 54].

All compound words are divided into syntactic and asyntactic. The first ones include words in which the order of components coincides with the order of words in syntactic phrases, while others are compound words in which the components are in combinations 
impossible for the syntax of the given language. In English there are words formed by the addition of two or more full-fledged words or stems. At the same time, different parts of the language can be combined, for example, noun + noun, adjective + adjective, noun + verb, etc. Compound words are written together, through a hyphen or as two separate words. There are no rules for writing such words [5, c. 19].

The intensive use of compound words reflects the synthetics of contemporary poetic thinking. Just as the detailed comparisons in the 20th-century artistic speech are gradually superseded by a metaphor, figurative means, expressed by combinations of words, are regularly replaced in modern texts - complex derivatives.

In the formation of compound words, we are guided not by logic, but by associations. We see or want to establish a connection between the two ideas, choosing the shortest possible path. What this connection is, usually turns out to be due to the context. Briefness takes over the clarity [6, p. 99]. In addition, among complicated words there are actually compound words formed as a result of the addition of two units, as well as difficult derivative words that were formed by addition, which was accompanied by some other derivation process (fixation, conversion, etc.).

Compounding is the formation of compound words by the combination of two stems or the stem and the whole word, which in the latter case acquires the status of morphemes and is also considered as the stem. The main objective of compounding is to facilitate communication. The numerous compound words combine in one word meaning, which, it would be necessary to convey by the whole word or sentence.

At present, activation of the process of compounding, caused by mobile changes in the language. In addition, the feature of the structure of compound words allows them to realize two main trends of language-to save language means (due to the ability of a compound word to express two and more thoughts simultaneously) and to artistic expression. The first tendency is widely manifested in compound words-terms that are characteristic of the language of scientific and technical texts. The second tendency - to expressiveness, emotional saturation - finds a vivid embodiment in the language of artistic works. However, this ability of compound words, in my opinion, is still poorly understood [7, p. 173].

Compound words are in many languages - Sanskrit, Greek, Swedish, Japanese, Chinese, Mongolian, Russian, English, German, and others. In a number of languages, they are relatively few, for example, in Latin. However, it can be argued that word-building by the process of compounding is peculiar to most languages of the world. The ability of the language to form compound words reflects the peculiarities of the vision of the world by the carriers of this language, national cultural specifics.

The translation of fiction works is fundamentally different from other types of translation. Such translation is a true art, since the translator must maintain the invariable contents of the original text, its sense; he has no right to embody any of his ideas. The fiction translation isn't literal therefore causes a set of disagreements among translators. Translator of fiction texts is a writer, who practically re-writes the book, reproducing it for readers $[8$, p. 71$]$.

The fiction translation must be clear. It is necessary to remember that, the laconicism and brevity of the translation, however shouldn't go to damage of clarity of reading of the text and ease of his understanding. The fiction translation must be literary, that is, fully comply with the generally accepted norms of the Ukrainian literary language.

As you know, the quality of translation depends largely on the goal set by the translator. There are three goals of translation of fiction texts: (1) an acquaintance of readers with the work of the writer, the works of which they cannot read themselves because of ignorance of the author's language; (2) an acquaintance of readers with the peculiarities of culture of another people, the transfer of originality of this culture; (3) an acquaintance of the reader with the contents of the book.

The understanding of the foreign-language text is difficult skill which demands preparation. Even knowledge of grammatical norms and lexicon doesn't guarantee excellent 
result yet. Difficulties of the translation from English into Ukrainian can arise for various reasons -from problems with definition of a word meaning to misunderstanding of syntactic sentence structure [9, p. 30].

The main task of any translator is to get an adequate original of the text that is as close as possible to its content and style. However, each language has its own peculiarities, therefore it is difficult to accurately convey the nuances of the meanings of a word. Leading ways of translating compound words are equivalent, analog, descriptive translation, transcription and decompression [10, p. 22].

In the initial analysis of the peculiarities of the translation of fiction text, one can distinguish the following series of problems encountered by all translators: (1) the specifics of the translation of stable expressions; (2) the problem of the translation of wordplay; (3) the need to take cultural differences into account. The specifics of the translation of stable expressions are not as complex as it may seem at first glance. Using the dictionary of stable phrases and speeches, as well as a dictionary of synonyms, you can easily select the most suitable translation. The problem of translating of wordplay is one of the most interesting moments in fiction translation - this is when the translated text has a humorous or ironic background. It is necessary to have a special skill to save the game of words, which is meant by the author [11, p. 183].

If to compare all presented translations of the series of novels by George Martin "A Game of Thrones" performed by different translators, then you can find differences in the expressions used by them, the analysis shows that the translations differ from each other, because each translator in his own way discovers the individuality of the author.

The personal style of George Martin is that he slightly shifts the usual sense of the word, forcing him to denote such a range of objects that do not exactly coincide with the range of objects that are usually designated by the word in the standard use.

We selected 562 examples, by the method of continuous sampling on the material of the series of novels by George Martin "A Game of Thrones". The following examples were analyzed and identified 13 word-formation models: N. + N. (111), Adj. + N. (99), N. + V. (80), N. + Adj. (77), V + N. (42), Adj. + Adj. (37), N. + V. + N. + N. (35), Adv. + Adj. (29), Num. + N. + N. (16), Adv. + Pron + N. (13), N. + V. + Adv. + Art. + N. (11), N. + Prep. + N. (7), N. + Adv. (5). As a rule, these words are translated by nouns and adjectives into Ukrainian language. These examples most accurately characterize the peculiarities of an individual style of the author.

Conclusions. Thus, English language is constantly evolving, new technologies are emerging, new sciences are emerging, and therefore there is a need for constant replenishment of the vocabulary to designate new concepts. Word formation studies ways to create new words and is the leading way to enrich the vocabulary of English. The most effective ways are fixation, conversion, telescoping and compounding.

Compound words act as an integral part of any language. The basic function of compound words enrich and enrich the vocabulary of English with new formations. Compounding is one of the most productive ways of word formation. Words with this method are formed by the addition of two stems.

Translation of fiction works is a complex process that requires high qualification. The goal of translators is to make the source text clear and acceptable to readers. Knowledge of the individual style of the author will help to more fully penetrate the atmosphere of the work, which in turn will help to make a better translation.

To translate compound words is not enough to use the dictionary, but you need to master the grammar and culture features of both languages at a high level. Before you begin to translate compound words of fiction texts, you need to get acquainted with the history of a particular country. Also, you should not rely entirely on the dictionary during translation, because these words are not always the fixed matches. And lastly, it is necessary to read carefully the original text in order to accurately convey the atmosphere of the work. 


\section{СЛОВОСКЛАДАННЯ ЯК НАЙПРОДУКТИВНІШИЙ ТИП СЛОВОТВОРУ У ХУДОЖНІХ ТЕКСТАХ АНГЛІЙСЬКОЇ МОВИ НА МАТЕРІАЛІ ЦИКЛУ РОМАНІВ ДЖОРДЖА МАРТIHА “A GAME OF THRONES”}

О. А. Шуменко, канд. філол. наук, доцент;

К. Василенко, студентка

Сумський держсавний університет,

вул. Римського-Корсакова, 2, м. Суми, 40007, Украӥна

E-mail:shuma-81@ukr.net, loveinsummertime@gmail.com

Стаття присвячена дослідженню особливостей процесу словоскладання в сучасній англійській мові. Нові слова з'являються постійно, велика їх частина утворена за допомогою словоскладання. У тих мовах, де наявний процес словоскладання, він є могутнім засобом поповнення словникового запасу і вдосконалення граматичного ладу мови. Словоскладання в порівнянні з деривацією, є системою більш активною, мобільною і відкритою. Словоскладання один з найпродуктивніших способів утворення слів. Слова за допомогою иього способу утворюються складанням двох основ.

Ключові слова: словоскладання, словотвір, складне слово,словотворча модель, продуктивний тип.

\section{СЛОВОСЛОЖЕНИЕ КАК САМЫЙ ПРОДУКТИВНЫЙ ТИП СЛОВООБРАЗОВАНИЯ В ХУДОЖЕСТВЕННЫХ ТЕКСТАХ АНГЛИЙСКОГО ЯЗЫКА НА МАТЕРИАЛЕ ЦИКЛА РОМАНОВ ДЖОРДЖА МАРТИНА «А GAMЕ OF THRONES»}

О. А. Шуменко, канд.филол. наук, доиент;

Е. Василенко, студентка

Сумской государственный университет,

ул. Римского-Корсакова, 2, м. Суми, 40007, Украина

E-mail: shuma-81@ukr.net, loveinsummertime@gmail.com

Словосложение является одним из древнейших способов словообразования, сохранившимся в английском языке и на современном этапе его развития. Статья посвящена исследованию особенностей процесса словосложения в современном английском языке. Новые слова появляются постоянно, большая их часть образована с помощью словосложения. В тех языках, где имеется прочесс словосложения, он является мошным средством пополнения словарного запаса и совершенствования грамматического строя речи. Словосложение, по сравнению с деривачией, является системой более активной, мобильной и открытой. Словосложение один из самых продуктивных способов образования слов. Слова с помощью этого способа образуются сложением двух основ.

Ключевые слова: словосложение, словообразование, сложное слово, словообразовательная модель, продуктивній тип.

\section{REFERENCES}

1. Means of word formation in modern English. - URL: http://bibliofond.ru/view.aspx?id=586565.

2. Pitel V. M. (2003). Determination factors for word formation. "Scientific notes" of Vinnytsia State Pedagogical University named after Mykhailo Kotsiubynsky. Vinnytsia, Ukraine. № 6. P. 192-198.

3. Kubryakova O. S. (1997). Semantics of syntax and some problems of the theory of word-formation. MSPIFL. №112, p. 123-133.

4. Meshkov A. D.(1985). Compounding in modern English language, textbook. $187 \mathrm{p}$.

5. Shepel Yu. O. (2017).Word-specific features of the terms of modern English and lexicographic practice. Visnyk Dnipro National University named after Oles Honchar. № 10, pp. 15-41.

6. Marchand A. (1969). The Categories and Types of Present-Day English WordFormation. Munchen : Reck, 1969. $379 \mathrm{p}$.

7. Nikolina N. A. (2013). Active processes in the sphere of addition of composing in the modern Russian language / Bulletin of the Nizhny Novgorod University named after N.I. Lobachevsky. Linguistics. N 6 (2). pp. $171-173$.

8. Karashchuk P. M. (1977). Compounding of English language. Moscow. 303 p.

9. Alexseev M. P. (1971). Problems of literary translation. Irkutsk : Academy, $320 \mathrm{p}$.

10. Vlakhov S. I. (1980). Untranslatable in translation. Moscow, Russia. 342 p.

11. The thorny path of an interpreter [Electronic source]. N. Y.: PenguinPutnamInc, 2007. - URLt: http://moiperevod.ru/info/articles/article_detail.php?id=96. 


\section{СПИСОК ВИКОРИСТАНИХ ДЖЕРЕЛ}

1. Засоби словотворення в сучасній англійській мові [Електронний ресурс] - Режим доступу : http://bibliofond.ru/view.aspx?id=586565.

2. Пітель В. М. Фактори детермінації словотворення / В. М. Пітель // Наукові записки Вінницького державного педагогічного університету ім. Михайла Коцюбинського. - 2003. - № 6. - С. 192-198.

3. Кубрякова Е. С. Семантика синтаксиса и некоторые проблемы теории словообразования Е. С. Кубрякова // МГПИИЯ. - 1977. - № 112. - С. 123-133.

4. Мешков А. Д. Словосложение в современном английском языке : учебник / А. Д. Мешков. - 1985. $187 \mathrm{c}$.

5. Шепель Ю. О. Словотвірні особливості термінів сучасної англійської мови і лексикографічна практика / Ю. О. Шепель // Вісник Дніпропетровського національного університету імені Олеся Гончара. Мовознавство. - 2017. - №10. - С. 15-41.

6. Marchand A. The Categories and Types of Present-Day English Word Formation / A. Marchand. - Munchen : Reck, 1969. - 379 p.

7. Николина Н. А. Активные процессы в сфере сложения в современном русском языке / Н. А. Николина // Вестник Нижегородского университеты им. Н.И. Лобачевского. Лингвистика. - 2013. - № 6(2).- С. 171-173.

8. Каращук П. М. Словообразование английского языка / П. М. Каращук. - Москва: Высшая школа,1977. $-303 \mathrm{c}$.

9. Алексеев М. П. Проблемы художественного перевода / М. П. Алексеев. - Иркутск: Академия, 1971. $320 \mathrm{c}$.

10. Влахов С. И. Непереводимое в переводе / С. И. Влахов, С. Флорин. - М. : Международные отношения 1980. - $343 \mathrm{c}$

12. Тернистый путь переводчика (2007) [Електронний ресурс] - N. Y. Penguin Putnam Inc., 2007. - Режим доступу : http://moiperevod.ru/info/articles/ article_detail.php?id=96

Received: 12 February 2018 
УДК 821.161.1/.2.09-054.72"1917/1939"

\section{МІФОЛОГІЧНІ МОТИВИ ТА ОБРАЗИ-АРХЕТИПИ МАТЕРІ У ТВОРАХ МАЛОЇ ПРОЗИ МІЖВОСННОЇ ДОБИ}

I. Р. Жиленко, докторант,

iD ORCID: https://orcid.org/0000-0002-1982-710X

Кам'янець-Подільський національний університет імені Івана Огієнка, вул. Огієнка, 61, м. Кам'янець-Подільський, 32300, Україна

E-mail: ariadna.irina365@gmail.com

Досліджуються міфологічні мотиви й архетипи матері в діалозі малої прози українських та російських письменників-емігрантів міжвоєнної доби. Спираючись на вчення К. Юнга про архетипи, доводиться, щуо архетип Великої Матері, який залишається протягом століть незмінним, породжує образи й сюжети у творах. У залучених для розгляду оповіданнях $i$ новелах окреслюються різноманітні міфологічні мотиви: помсти, прохання милостині, сліпоі материнської любові, Ніобеї (матері-страдниці), Ати (підміни дитини), Ананке (фатальноі зустрічі),Юди (матері-зраднииі), Фурії (материнського прокляття й помсти), маски (захисноі оболонки),чужого (невпізнання власної дитини), манкуртизму (забуття), Мнемозини (спогаду), блудного сину.

Підкреслено, щз мотиви з часом видозмінюються, втрачають і набувають нових деталей, виявляючи себе у новому змісті, адже вони часто поєднуються, складаючи «зерно сюжету» (О. Веселовський). Художні парадигми украӥнських та російських письменників у зображенні основних архетипів та мотивів материнської тематики є типологічно схожими і в багатьох випадках переплітаються.

Хоча материнський образ-архетип є амбівалентним, все ж у творах малої прози домінантним є позитивний образ матері. Основу для нього складає архетип Великої Матері, який відігравав провідну роль у творах І. Шмельова, Л. Верховинки, І. Гаврилюка, Теффі, У. Самчука, В. Софронова-Левицького, Б. Лепкого. Мати-берегиня, часто забуваючи про власне життя, йде на все заради щастя дитини, тому спільним майже для усіх аналізованих творів є мотив жертовності.

Ключові слова: міфологічні мотиви, К. Юнг, архетипи, Велика Матір, жертовність.

DOI: $10.21272 /$ Ftrk.2018.10(1)-15

Вступ. Один із найважливіших вічних (традиційних) образів світової літератури, до якого в усі часи зверталися письменники - образ Матері. В українській та російській літературах він давно став триєдиним: образ рідної матусі- образ Богоматері - образ Батьківщини. Після жовтневого перевороту 1917 року важким випробуванням для українських та російських письменників стала еміграція. Для багатьох із них материнська любов була тією зіркою, що вказувала дорогу в майбуття, вселяла віру у власні сили і давала наснагу до життя. Свідченням надзвичайної поваги до жіночої статі $є$ написання українським письменником О. Вараввою-Кобцем понять Мати і Дівчина лише з великої літери.

(C) Жиленко I. Р., 2018 
У роботах багатьох науковців досліджувалася означена тема. Материнський код вивчала Н. Зборовська; материнський і жіночий архетипи, символи - А. Амбіцька, С. Ігнатьєва, О. Клінг, В. Пропп, Т. Пуларія, Н. Пушкарьова, Б. Рибаков, Т. Шестопалова; образ Божої матері - І. Кметь, Н. Лебединцева, О. Матушек; образ матері, стильові особливості - О. Шлома, Л. Громик, Т. Веретюк, О. Пастушенко, Н. Чупрінова, I. Івакіна, С. Ленська, С. Максимчук-Макаренко, М. Мелексетян, Н. Білоус та інші. Незважаючи на велику кількість робіт, не так часто звертаються науковці до вивчення материнської тематики на компаративному рівні. Дослідження творчості письменників еміграції міжвоєнної доби знаходиться на початковій стадії, у чому й полягає актуальність нашої роботи.

Мета дослідження - простежити міфологічні мотиви й образи-архетипи матері у малій прозі українських та російських письменників-емігрантів міжвоєнної доби.

Реалізація мети передбачає вирішення таких завдань: визначити основні міфологічні мотиви, пов'язані з материнськими образами; з'ясувати особливості трактування письменниками образу матері через рецепіювання архетипу Великої Матері та переосмислення міфопоетичних традицій у його зображенні.

Об’скт роботи - мала проза Б. Лепкого, У. Самчука, Теффі, I. Шмельова, Лесі Верховинки, І. Гаврилюка, В. Софронова-Левицького та інших.

Предметом дослідження вибрано архетипи й міфологічні мотиви у творах малої прози українських та російських письменників-емігрантів міжвоєнної доби.

Виклад основного матеріалу. Галузь тематології містить такі традиційні поняття, як міфи й архетипи, образи й сюжети, тож спробуємо їх узгодити.

Архетип Великої Матері (інші назви Божа Матір, Софія, Діва) $є$ одним із найважливіших архетипів, визначених К. Юнгом. Їх динаміка лежить в основі міфів, символіки художньої творчості. У роботі «Психологічні аспекти архетипу матері» психолог писав: «Як і кожен архетип, архетип матері має воістину неймовірну безліч аспектів. Згадаю лише деякі типові форми: мати або бабуся конкретної людини, хрещена мати або свекруха й теща, будь-яка жінка, 3 якою людина знаходиться в деяких відносинах, а також годувальниця й нянька; це може бути родоначальниця або представниця білої раси - у вищому, переносному сенсі - богиня, особливо мати бога, діва (наприклад, Деметра або Кора), Софія (як мати-кохана...)» [1].

Провідну роль відіграє архетип матері в українській та російській літературах, де часто існує під іменем Берегині. Як зазначає В. Войтович, це богиня добра, захисту людини, оселі, малих дітей від хвороб та інших злих сил [2, с. 25]. Згідно 3 концепцією академіка Б. Рибакова зв’язок Берегині з поняттями «берег» і «оберігати» співвідносить їх з добрим началом. Твори материнської тематики містять різні мотиви, але архетипово тяжіють до Великої Матері, провідне завдання якої оберігати. «Любовь материнская отдает свой пурпур и свой виссон», - зазначає Теффі [3]. А отже основний мотив - жертовності матері-берегині - є провідним.

Зазвичай письменник у своїх творах залишає для нащадків закодоване повідомлення, яке позначається за допомогою його конструктів, архетипів. Однак сам архетип, на думку Л. Коробко, ще не має конкретного втілення. Він провокативна субстанція, 3 якої народжуються всі наступні літературні форми [4, c. 89].

Так, у творі І. Гаврилюка «Жах» в образах матері й сина репрезентовано ідею визволення України: коли стають зайвими слова, починається боротьба. Архетип Великої Матері став основою для образу «неньки нещасного сотника», яка оббиваючи пороги усіх більшовицьких інстанцій, забувала про все, крім сина. «Худа, виснажена, з непокритою головою, зчорніла від голоду й нещастя», жінка прийшла до голови губернської «чека», «надлюдським голосом переказувала всі муки матері» [5, с. 17]. Знесилившись, стара мати впала на коліна, але не дочекалася милосердя. I тоді зірвалася на ноги й кинулася на кривдника, уп'явшись «старечими зубами у його горло» - мотив Фурії, помсти матері за тортури над сином. Ще один міфологічний мотив - Танатос - реалізується через архетип Смерті. Івась, побачивши матір на 
долівці, всю у синцях, зрозумів силу материної любові і всю іï велич. Сотник вірний син України - вважав недоречним перед «насильниками-чужинцями» принижуватися, тому терпить тортури. А українська Мати-Берегиня підтримала: «Нехай катують, нехай мучать, але не роби... [не видавай своїх - I. Ж.]» [5, с. 18]. Синові захотілося зробити доброчинство й покласти «край мукам цієї найріднішої людини», тому, урочисто перехрестивши, дав їй отруту.

Спільним для творів Б. Лепкого «Ах, як же цей папір палить!» і Теффі «Мать», написаних на тему еміграції, є мотив прохання милостині. Український письменник у психологічній новелі змалював хвилювання жінки-емігрантки, яка разом із синомстудентом, що «на лікаря вчиться», змушена стояти 3 простягненою рукою. Виправдане використання Лепким ряду слів, що підкреслюють усвідомлення нею вимушених дій: «нервово й поспішно відчиняє двері», «зиркнула направо й наліво», «перебігла город», «біжить... Скоро! Скоро! Скоро!». Вона заздрить навіть статуям, які «не чують ні голоду, ні зимна... Не знають, що таке інфляція», не дізнається й покійний батько, що «з ними так зле, що нема вже й за що обіду зварити». Героїня зносить сміх і знущання таксистів. Рука, яку вона простягла для милостині - «важка, як з олова» і «чужа така, мов не іiі. Деревіє, болить...». Паперова асигнація, отримана від милосердного пана, нещадно палить жінці руку [6, с. 342-343].

Героїня оповідання Теффі - ще один зразок жертовності матері. Та, на відміну від твору Лепкого, гроші, які пані Бове «выклянчивала по нескольку франков» у російських емігрантів, їй «не палять» рук. Колись скромна та чесна, зараз вже не відчувала ні стиду, ні своєї брехні, коли обіцяла невдовзі повернути борг.

Провідним у творі є мотив сліпої материнської любові. Вперше у світовій літературі вислів «Любов сліпа» зустрічається у давньогрецького філософа Платона: «Любов засліплює, бо люблячий стає сліпим по відношенню до предмета своєї любові». Для Шарлотти Бове їі сімнадцятирічний хлопчик Поль назавжди залишився тією крихіткою, заради кого ӥй хотілося жити, чиї примхи вона завжди виконувала, для кого вона розпочала нову еру свого життя. Жебракування задовольняло Шарлотту перш за все тому, що вона відчувала «чрезмерное счастье», коли синневіглас хвалив іiі за роздобуті гроші. Материнська сліпота врешті зіграла жахливу роль. Вона навіть не зразу усвідомила, що син скоїв злочин, вбивши дружину, щоб привласнити іiї спадщину. Наприкінці твору з'являється мотив чужого - невпізнання власної дитини. Коли Поля ввели до зали суду, мати не зразу впізнала сина, бо вирішила, що це - злодій. Пізніше, розгледівши «ямочки на щеках», вона рухнула перед ним на коліна. Конвой змушений був захищати матір - «ведьму, убившую невестку из ревности к сыну»- від обуреного натовпу [3]. К. Юнг писав: «Усі ці символи можуть мати позитивний, сприятливий, або ж певний негативний, nefas сенс. Амбівалентний аспект - у богинь долі, нечестивий - у відьми, дракона» [1]. Отже, у свідомості людей відбулася трансформація архетипу Матері в негативний архетип відьми, що є свідченням віддзеркалення колективного світогляду людей.

У творах Лепкого й Теффі поруч із архетипом Великої Матері з'являється архетип Маски (захисна оболонка). Маркером його в українського автора $є$ своєрідна метаморфоза матері, яка «робиться мала, така маленька, що сама себе не впізнає у дзеркалі». Одягнувши чорну велику хустку так, щоб лише «ніс і очі видно», жінка крадькома пробирається на край міста, де б іiі ніхто не впізнав. I рухається вона поспіхом, намагаючись нікому із знайомих не потрапити на очі. [6, с. 342]. Шарлотта також поєднує обидва архетипи: «В тусклых буднях, в лохмотьях и рубище подымается по высоким скалам, куда ведет ее тихая тень с огненным венчиком на голове, закрывающая бедным плащом грудь свою, пронзенную семью мечами» [3]. Героїні обох творів змушені ховатися за масками, щоб зберегти власне «Я», бо маска, яку підтримує натовп, це маска «людини натовпу».

У діалогічні відносини 3 оповіданням Теффі «Мать» вступає твір Лесі Верховинки «Мати», що помітно як у заголовках, так і в мотивах жертовності й сліпої материнської любові. Портретні характеристики героїнь дещо схожі. Мати в 
оповіданні Теффі «..постарела, опустилась, стала неопрятной, забывала причесаться»; «Сухое лицо, острое, как сабля, выглядывало из-под шляпки со сломанным, отслужившим службу фазаньим пером. Покрытое красными пятнами нервной экземы, оно казалось пылающим. Сизые губы улыбались, и в черных орбитах, дрожа, исходили жемчужным светом глаза» [3]. 3 перших рядків твору Лесі Верховинки постає Брана: «...можна іiі бачити на вулицях маленького містечка - як тягне за собою старі ноги, обуті в подерті черевики, тяжкі, як її доля. Маленька ростом, мов дванадцятилітня дитина, з маленьким поморщеним лицем і з патлами брудного вже сивіючого волосся, що висуваються 3-під хустки...» [7, с. 149]. Обидві характеристики $є$ свідченням того, що їх турбували лише діти, на себе ж матері не зважали, відмовляючи майже в усьому.

Сенсом життя старої Брани-перекупниці є дочка Сара. Місце жінки - «під дверима, з руками, зложеними на животі». Вона ладна годинами стояти так, якби лиш переконати людину, поторгуватися, і коли їй це вдається, на вустах розцвітає щаслива «усмішка, повна таємного щастя» [7, с. 150]. Брана вперта, нахабна і скупа, вона «трясеться над кожним грошем», але для Сари купує найкращу каву, бо це улюблений напій донечки. Мати довго й наполегливо збирає придане, щоб віддати дочку заміж за достойного чоловіка. Сама мріє про той час, коли зможе нарешті відпочити біля своєї донечки у заможному будинку. Та ось Сара заміжня, і щаслива мати відправляється до неї аж на другий кінець міста. Однак в голосі дочки чує мати чужі ноти, бо тій соромно за старі материні речі, клунки з дірками. Сподівання на тихе життя поруч із Сарою були марними, бо вони 3 чоловіком не можуть «тепер прийняти ії до себе», «може, колись пізніше», «але не тепер». Тематично твір Л. Верховинки знаходиться близько до роману О. Бальзака «Батько Горіо», який також усе життя присвятив дочкам, віддав їм останні гроші, а помер у злиднях. Брана й далі «ходить по домах і скуповує речі», але суворі реалії буття диктують інший настрій. К. Юнг вважав, що інший бік архетипу Матері - «безодня й царство мертвих», що й бачимо в оповіданні української письменниці. В її очах - «глибока пропасть смутку», яка росте 3 кожним днем, аж поки стане «пропастю смерті» [7, c. 160].

Архетип Великої Матері-Берегині є провідним і у творі І. Шмельова «Рассказ об одной старухе». Про типовість образу жінки свідчить думка автора: «Да в каждой губернии таких старух найдется». Його героїня «махонькая была, сухенькая, а одна ломила - и по дому, и в поле. Легкая была на ногу, кость да жилка, и годов уж за шестьдесят. <..> И характером настойчивая была, сурьезная» [8, с. 154]. Зображаючи життя старої на тлі великих соціальних потрясінь - війни, революції, колективізації, Шмельов окреслює своєрідний образ-символ самої Росії тих важких літ. У творі присутній міфологічний мотив манкуртизму, притаманний синові. Поява цього мотиву пов'язана 3 романом Ч. Айтматова «Плаха», який відродив одне із давніх вірувань свого народу. Глибинний зміст манкуртизму міститься у тому, що людина степу, потрапляючи до полону, підлягала таким знущанням, котрі цілеспрямовано позбавляли іiї пам'яті й стирали усю інформацію про минуле. Саме таким «Иваном, не помнящим родства», виявився син, який і до війни мало чим допомагав матері («спьяну побьет когда»), а потім пропав без вісти - мотив блудного сина. Притча про блудного сина, який пішов 3 дому i, блукаючи в чужих краях, втратив спадщину, міститься у Євангелії від Луки (гл. 15). Героїня Шмельова поплакала, отримавши вість, що сина вбито, та нічого не вдієш - треба онуків ставити на ноги. Порятунком від голоду був складним шлях «на Волгу да за Тамбов», куди прямували люди обмінювати речі на борошно. Мусила й стара їхати. Дорогою назад більшовицький загін особливого призначення почав вести обшук «спекулянтов». Стара «затряслась-обмерла, в мешки вцепилась, кричит: «Убейте лучше, не дамся!» [8, с. 169]. В одному із особистів вона впізнала сина і почала кричати: «Во-он ты где?!! с ими?!.. у родных детей хлеб отымаешь?!.. Мы погибаеммучимся: а ты по дорогам грабишь?!.. родную кровь пьешь?!!, да будь ты... проклят,

«Філологічні трактати», Том 10, № 1 ' 2018 